$1-1-1910$

\title{
Spraying for the Codling Moth : Eastern and Western Methods Compared : a Preliminary Report
}

W.E. Rumsey

Follow this and additional works at: https://researchrepository.wvu.edu/ wv_agricultural_and_forestry_experiment_station_bulletins

\section{Digital Commons Citation}

Rumsey, W. E., "Spraying for the Codling Moth : Eastern and Western Methods Compared : a Preliminary Report" (1910). West Virginia Agricultural and Forestry Experiment Station Bulletins. 127.

https://researchrepository.wvu.edu/wv_agricultural_and_forestry_experiment_station_bulletins/127 
West Virginia University Libraries

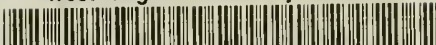

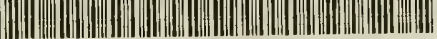

308021008961173 


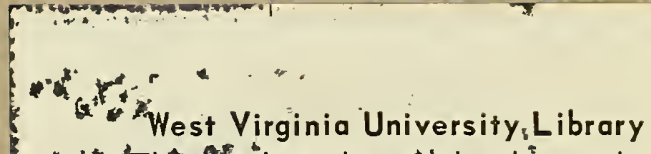

15 the date indicated

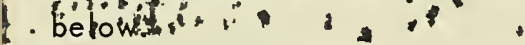

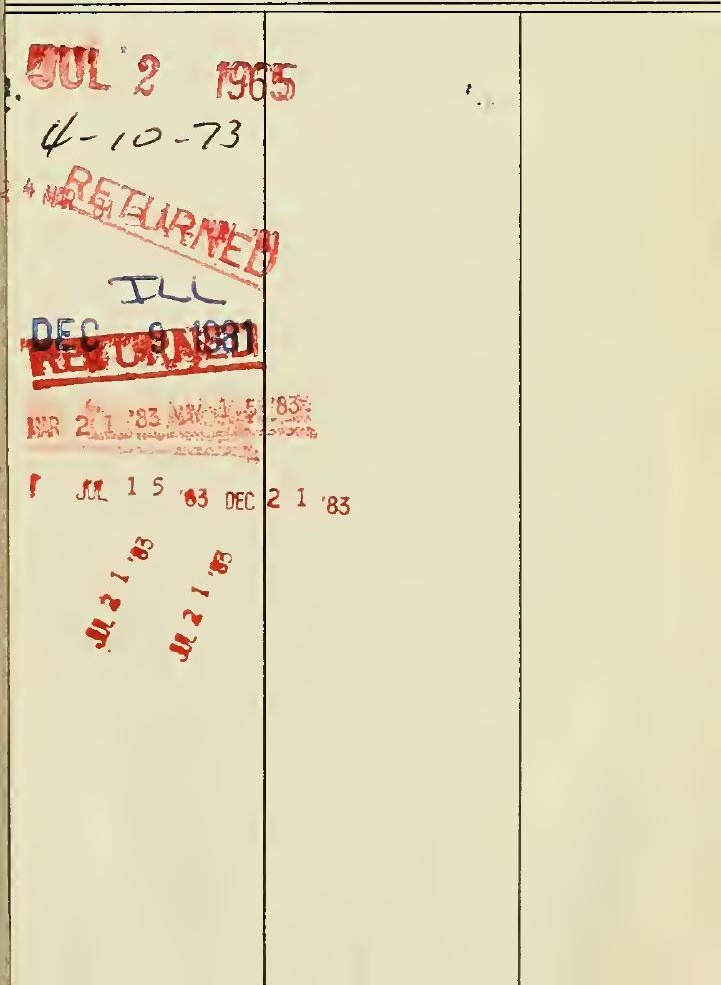


Digitizea by the Internet Archive in 2010 with funding from

tyl asis Members and Sloan Foundator 


\section{WEST VIRGINIA UNIVERSITY \\ AGRICULTURAL EXPERIMENT STATION \\ MORGANTOWN, W. VA.}

\section{Spraying for the Codling Moth}

\section{Eastern and Western Methods Compared}

(A PRELIMINARY REPORT)

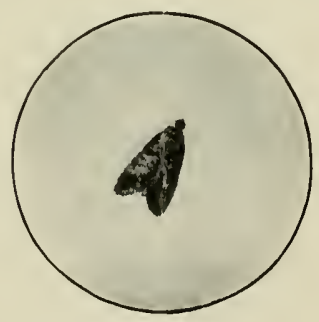

ENTOMOLOGICAL DEPARTMENT

[The Bulletins and Reports of this Station will be malled free to any citizen of West Virginia upon written application. Address Director of Agricultural Experiment Station, Morgantown, W. Va.] 


Hon. M. P. Shawkey .................... Hon. J. B. Finley . . . . . . . . . . . . Parkersburg, W. Va. Hon. George S. Liaddey .................... Hon. G. A. NortilcotT................ Huntington, W. Va. How. M. C. Lovgh. ........................

President of the Board of Regents............ P. Shawkey President of the University.............. B. Preninton Treasurer .Thomas E. Hodges

\section{THE BOARD OF CONTROL.}

Hon. JaMes F. LAKin ...................... Charleston, W. Va. Hon. John A. Sheppard................. Charleston, W. Va. Hon. Thomas E. Hodges................. Charleston, W. Va.

\section{STATION STAFF}

James H. Stewart, A. M..........Director and Agriculturist Bert H. Hite, M. S............ Vice Director and Chemist

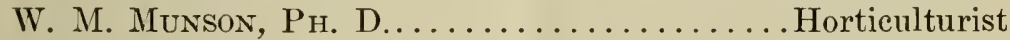
W. E. Rumsey, B. S. AGr. . . . . . . . . . . . Entomologist

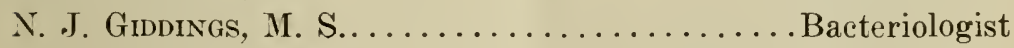
Horace Atwood, M. S. Agr...........Assistant Agriculturist

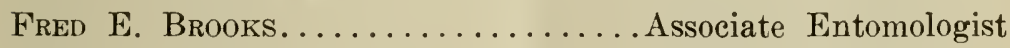
Frank B. Kunst, A. B............. Assistant Entomologist Chas. E. Weakley, Jr................ Assistant Chemist J. H. Berghuis Krak.................Assistant Chemist

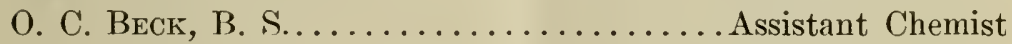
A. L. DACY, B. Sc................ Assistant Horticulturist

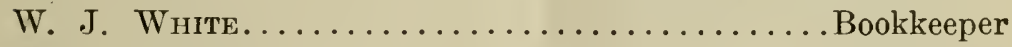

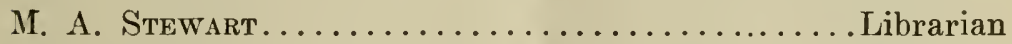

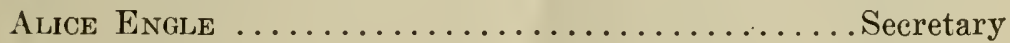

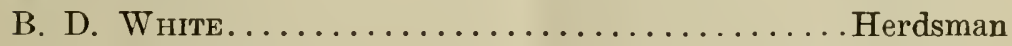
Theo. F. Iмвасн. Greenhouseman 



\section{Spraying for the Codling Moth}

\section{Eastern and Western Methods Compáred}

(A PRELININARY REPORT)

\section{W. E. Rumsey}

\section{INTRODUCTION}

Undoubtedly the worst enemy of the apple crop in West Virginia is the codling moth-the insect that causes the wormy apple. This pest is taking altogether too much toll from the apple growers of our State and as our fruit industry is going forward by leaps and bounds more attention must be given to the control of this arch enemy of the orchardist.

A great amount has been written about this insect, and much time and money spent in carrying on experiments to devise ways and means for controling it. At last spraying with arsenical poisons has become the practical method by which this pest is kept in check. However, the manner of applying the poison is not, apparently, definitely settled by the entomologists of the different sections of the United States. When the Eastern entomologists seemed to have hit upon just the way of applying the material-a fine mist spray with a medium amount of pressure applied two or three times during the season, the first spraying just after the petals have fallen-their Western colleagues come forward with the statement, backed up with results obtained in their territory, that a coarse-highpressure spray applied once at the right time (just after the petals fall) will give as good or even better results than are secured by the application of three or four mist sprays. The reasons advanced for the good results obtained by using the coarse-high-pressure spray is that with this method the poison 
is forced into the lower calyx cup of the forming apple where it remains ready to be eaten by the young worm when it begins to mine into the apple through the calyx end; while with a mist spray no poison is put into this carity, merely being left within the surface of the outer calyx cup, and thus not as likely to be eaten by the worm in its passage to the lower cup where it enters the fruit. "The calyx cups must be filled" is the slogan of our Western friends if one spraying is to be successful. It is a well known fact that a large majority of the first brood worms enter the apples through the calyx or blossom end; therefore, if these worms are all killed there will not be enough moths develope to lay eggs 'for the second brood of worms to make it necessary to spray the second time.

Having the Western entomologists firing hot shot into us, at meetings of the American Association of Economic Entomologists, concerning their excellent results in spraying for the codling moth with a coarse-high-pressure spray we decided to make a comparative test of the two methods. While we expect to continue this experiment at least another year or two and then give the public our final results together with a detailed account of the life history and habits of the codling moth for West Virginia we think the findings of last season worthy of a short preliminary report on the subject.

Two spraying tests were carried on during the season of 1909. One in Upshur county, near French Creek by F. E. Brooks on a block of seven year old York Imperial trees, and the other in Berkeley county, near Martinsburg by the writer on a block of sixteen year old Ben Davis trees. The former experiment was on a smaller scale than the latter and the results obtained will appear in our final publication on the codling moth.

\section{The Experiment Outlined.}

On page 129 is a diagram showing the location of the block of Ben Davis trees as regards the balance of the orchard in the 


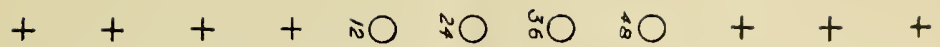

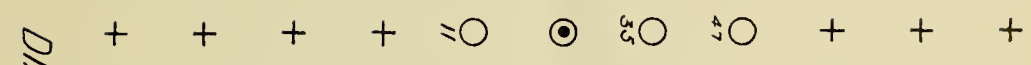

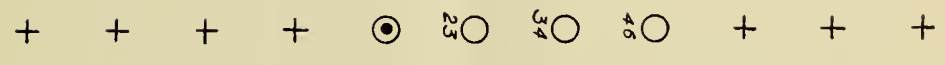
$3++++20 \approx 0 \leqslant 0 \leqslant 0 \leqslant \theta+$

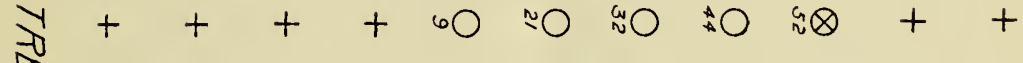

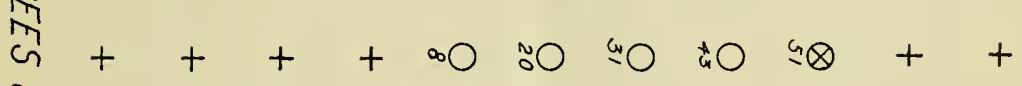
$\hat{s}++++.0$ है

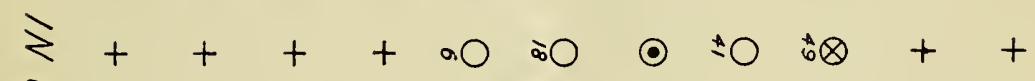

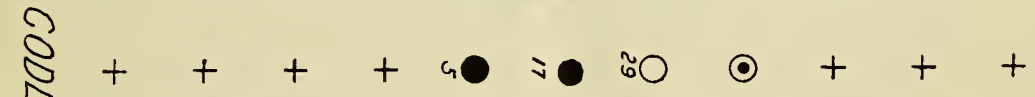

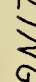

๙ ++++.0 ล०

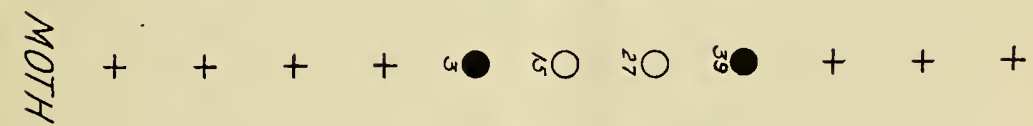
जी

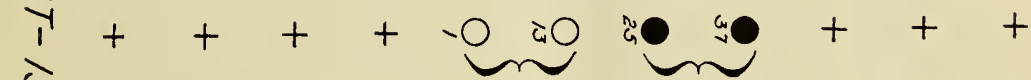
6
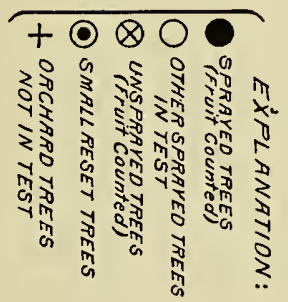

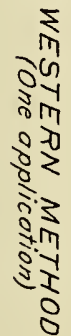

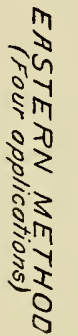

$+++$

$+\quad+\quad+$

$+++$

$+\quad+$ 
Berkeley county experiment. Twenty-four trees were used in the Western method of application and a like number were sprayed according to the Eastern method. Five trees from each of these two plots, as indicated on the diagram, were selected from which to make counts of the fruits for comparing the two methods, also five trees were used as checks that were not to receive any kind of spray during the season to serve as a basis in figuring out the effect of spraying. By an oversight of the workmen check tree No. 49 was sprayed with the mist spray when the first application was made; namely, on May 13 th.

By referring to the diagram of the orchard it will be seen that the block of trees selected for the test has other apple trees about it. All those on the side next to the check trees and mist sprayed ones were treated by the owner for the codling moth. The continuation of the orchard on the side adjoining the trees treated according to the Western method is composed of younger trees just coming into bearing, but were not sprayed by the owner for the codling moth as expected. This fact no doubt accounts for many wormy apples by the second brood of worms in the fruit from the trees where the coarse-high-pressure spray was applied.

\section{Methods of Treatuent.}

The block of trees designated as "Eastern method" was treated as follows: On May 13th, 1909, just after the petals had fallen, the trees were sprayed with Bordeaux mixture(3-550 formula) to which was added three pounds of arenate of lead to each fifty gallons of liquid, using double vermorel nozzles with a pressure of 100 pounds on a gasoline power sprayer. The second spray was applied in like manner and with the same kind of material on May 28th. This was made especially to lessen the injury of the plum curculio. The third spraying was done on June 16th and the fourth and last application was made on July 22nd. The combination of Bordeaux and arsenate 
of lead is to reach two kinds of trouble with one spraying; namely, the codling moth and curculio on the one hand, and apple scab and similar diseases on the other.

The trees used in the "Western method" of treatment were sprayed on the afternoon of May 12th, 1909 (calyx in the same condition as with the other method) using one pound of arsenate of lead to fifty gallons of water, with a bordeaux nozzle attached to the extension rod at an angle of $45^{\circ}$ and the pressure gauge on the gasoline sprayer registering from 200 to 250 pounds. By means of the "crook" on the extension rod the coarse spray, with the high pressure behind it, could be shot directly into the open calyces on all parts of the tree. This was the only spraying of any kind that these trees received during the entire season. No diseases were prevalent in this orchard, hence the apples from these trees where no bordeaux was used were in excellent condition at picking time.

\section{Results on Counted Fruit.}

Beginning on June 23rd all drop fruits from the five trees each of the two methods tested and the five check trees alreary mentioned, fifteen in all, were examined at intervals during the season up to picking time. Six such observations were made. The number of codling moth apples were noted, care being taken to record those wormy at the calyx, side, and stem. The result. of these counts have been arranged in tables (see pages 132, 134, and 136) to show the amounit of wormy fruit and to indicate the position where the worms entered the apples from the sprayed and unsprayed trees in the test. Table I (p. 132) shows the total per cent wormy of the drops for the season of the three different groups, which is 2.2 per cent for the coarse-high-pressure treatment; 4.3 for the mist sprayed and 29.6 per cent for the unsprayed trees. Tree No. 49 intended for a check but received one mist spray, as already stated, gives an inkling of what may be expected by the application of one mist spray at the proper 


\section{TABLE I}

\section{Record of Codling Moth Work-Dropped Fruit for Season.}

Western Method of Spraying-Coarse Spray, High Pressure, One Application

\begin{tabular}{rccccccc}
\hline $\begin{array}{c}\text { Tree } \\
\text { No. }\end{array}$ & $\begin{array}{c}\text { Calyx } \\
\text { wormy }\end{array}$ & $\begin{array}{c}\text { Side } \\
\text { wormy }\end{array}$ & $\begin{array}{c}\text { Stem } \\
\text { wormy }\end{array}$ & $\begin{array}{c}\text { Total } \\
\text { wormy }\end{array}$ & $\begin{array}{c}\text { Sound } \\
\text { fruit }\end{array}$ & $\begin{array}{c}\text { Total } \\
\text { fruit }\end{array}$ & $\begin{array}{c}\text { Per cent } \\
\text { wormy }\end{array}$ \\
2 & 3 & 13 & 7 & 23 & 755 & 778 & 2.95 \\
3 & 0 & 11 & 2 & 13 & 287 & 300 & 4.33 \\
5 & 0 & 7 & 0 & 7 & 686 & 693 & 1.01 \\
16 & 2 & 5 & 1 & 8 & 502 & 510 & 1.56 \\
17 & 1 & 10 & 6 & 17 & 746 & 763 & 2.22 \\
& -6 & 46 & 16 & 68 & 2976 & 3044 & $2.2 \%$ \\
\hline
\end{tabular}

Eastern Method of Spraying-Mist Spray, Medium Pressure, Four Applications

\begin{tabular}{|c|c|c|c|c|c|c|c|}
\hline $\begin{array}{l}\text { Tree } \\
\text { No. }\end{array}$ & $\begin{array}{l}\text { Calyx } \\
\text { wormy }\end{array}$ & $\begin{array}{l}\text { Side } \\
\text { wormy }\end{array}$ & $\begin{array}{l}\text { Stem } \\
\text { wormy }\end{array}$ & $\begin{array}{l}\text { Total } \\
\text { wormy }\end{array}$ & $\begin{array}{l}\text { Sound } \\
\text { fruit }\end{array}$ & $\begin{array}{l}\text { Total } \\
\text { fruit }\end{array}$ & $\begin{array}{l}\text { Per cent } \\
\text { wormy }\end{array}$ \\
\hline 25 & 23 & 17 & 1 & 41 & 446 & 487 & 8.41 \\
\hline 37 & 10 & 11 & 4 & 25 & 296 & 321 & 7.78 \\
\hline 38 & 8 & 10 & 1 & 19 & 635 & 654 & 2.90 \\
\hline 39 & 6 & 5 & 1 & 12 & 434 & 446 & 2.91 \\
\hline \multirow[t]{2}{*}{40} & 2 & 6 & 0 & 8 & 503 & 511 & 1.54 \\
\hline & 49 & 49 & 7 & 105 & 2314 & 2419 & $4.3 \%$ \\
\hline
\end{tabular}

Check (Unsprayed) Trees-For Comparison

\begin{tabular}{|c|c|c|c|c|c|c|c|}
\hline $\begin{array}{l}\text { Tree } \\
\text { No. }\end{array}$ & $\begin{array}{l}\text { Calyx } \\
\text { wormy }\end{array}$ & $\begin{array}{c}\text { Side } \\
\text { wormy }\end{array}$ & $\begin{array}{l}\text { Stem } \\
\text { wormy }\end{array}$ & $\begin{array}{l}\text { Total } \\
\text { wormy }\end{array}$ & $\begin{array}{l}\text { Sound } \\
\text { fruit }\end{array}$ & $\begin{array}{l}\text { Total } \\
\text { fruit }\end{array}$ & $\begin{array}{l}\text { Per cent } \\
\text { wormy }\end{array}$ \\
\hline 50 & 330 & 71 & 11 & 412 & 1183 & 1595 & 25.83 \\
\hline 51 & 379 & 63 & 20 & 462 & 1254 & 1716 & 26.92 \\
\hline 52 & 311 & 41 & 13 & 365 & 507 & 872 & 41.85 \\
\hline \multirow[t]{2}{*}{53} & 165 & 56 & 9 & 230 & 542 & 772 & 29.79 \\
\hline & 1185 & 231 & 53 & 1469 & 3486 & 4955 & $29.6 \%$ \\
\hline
\end{tabular}

Tree No. 49. Intended for check, but by mistake mist sprayed May 13

$\begin{array}{lccccccc}\text { Tree } & \text { Calyx } & \text { Side } & \text { Stem } & \text { Total } & \text { Sound } & \text { Total } & \text { Per cent } \\ \text { No. } & \text { wormy } & \text { wormy } & \text { wormy } & \text { wormy } & \text { fruit } & \text { fruit } & \begin{array}{c}\text { wormy } \\ 49\end{array} \\ 14 & 7 & 0 & 21 & 566 & 587 & 3.57 \%\end{array}$


time; the drops in this case showing 3.5 per cent wormy. In these tables of drop apples it is interesting to note the great excess of calyx wormy fruit in the Eastern, or mist sprayed trees over that of the Western, or coarse-high-pressure spraying. The former gives a total of 49 while that of the latter has but 6 . The side wormy run about the same -49 for the mist and 46 for the coarse spray. Stem wormy is more pronounced in the coarse-high-pressure treatment-16 to 7 . So much for the drops. We will now turn our attention to the tables showing the results at picking time. However, before taking up this matter it might be stated that on July 21st the fifteen trees used for counts were gone over and all the wormy apples that could be found were picked. Therefore, the greater amount of wormy fruit in the harvested crop as shown in table II (page 134) is from the second brood of worms. This table shows a total of 2.8 per cent of picked fruit wormy where the one coarse-highpressure spray was used and a total of 2.9 per cent wormy where the four mist sprays were applied. The percentage wormy of the unsprayed trees is 38.3 . In this case tree No. 49 (mist sprayed once by mistake) shown 12.5 per cent wormy. The proximity of the check trees undoubtedly augmented the wormy fruit on this tree. In the picked apples, as with the drops, the calyx wormy is much more marked in the mist sprayed than in the coarse-high-pressure sprayed trees. The side and stem wormy apples are apparently much greater where the Western method was followed than where the Eastern was used: however, the difference is not so marked when the amount of fruit from the trees receiving the two kinds of spraying is taken into consideration.

Table III (p. 136) represents the total fruit for the season from the fifteen trees and is a combination of the two previous tables.

The average per cent wormy of the total crop where the onecoarse-high-pressure spray was used is 2.6 and that for the mist sprayed trees is 3.3. The checks, or unsprayed trees show an average of 34 per cent wormy. Tree No. 49 show the wormy 


\section{TABLE II}

Record of Codling Moth Work-Picked Fruit

Western Iethod of Spraying-Coarse Spray, High Pressure. One Application

\begin{tabular}{|c|c|c|c|c|c|c|c|}
\hline $\begin{array}{l}\text { Tree } \\
\text { No. }\end{array}$ & $\begin{array}{l}\text { Calyx } \\
\text { wormy }\end{array}$ & $\begin{array}{l}\text { Side } \\
\text { wormy }\end{array}$ & $\begin{array}{l}\text { Stem } \\
\text { wormy }\end{array}$ & $\begin{array}{l}\text { Total } \\
\text { wormy }\end{array}$ & $\begin{array}{c}\text { Sound } \\
\text { fruit }\end{array}$ & $\begin{array}{l}\text { Total } \\
\text { fruit }\end{array}$ & $\begin{array}{c}\text { Per cent } \\
\text { wormy }\end{array}$ \\
\hline $\begin{array}{r}2 \\
3 \\
5 \\
16 \\
17\end{array}$ & $\begin{array}{l}8 \\
0 \\
2 \\
2 \\
3\end{array}$ & $\begin{array}{r}103 \\
38 \\
54 \\
34 \\
54\end{array}$ & $\begin{array}{r}13 \\
10 \\
6 \\
6 \\
4\end{array}$ & $\begin{array}{r}124 \\
48 \\
62 \\
42 \\
61\end{array}$ & $\begin{array}{l}2429 \\
2328 \\
2880 \\
1991 \\
2050\end{array}$ & $\begin{array}{l}2553 \\
2376 \\
2942 \\
2033 \\
2111\end{array}$ & $\begin{array}{l}4.85 \\
2.02 \\
2.10 \\
2.06 \\
2.88\end{array}$ \\
\hline & 15 & 283 & 39 & 337 & 11678 & 12015 & $2.8 \%$ \\
\hline
\end{tabular}

Eastern Method of Spraying-Mist Spray, Medium Pressure, Four Applications

\begin{tabular}{|c|c|c|c|c|c|c|c|}
\hline $\begin{array}{l}\text { Tree } \\
\text { No. }\end{array}$ & $\begin{array}{l}\text { Calyx } \\
\text { wormy }\end{array}$ & $\begin{array}{l}\text { Side } \\
\text { wormy }\end{array}$ & $\begin{array}{l}\text { Stem } \\
\text { wormy }\end{array}$ & $\begin{array}{l}\text { Total } \\
\text { wormy }\end{array}$ & $\begin{array}{l}\text { Sound } \\
\text { fruit }\end{array}$ & $\begin{array}{l}\text { Total } \\
\text { fruit }\end{array}$ & $\begin{array}{l}\text { Per cent } \\
\text { wormy }\end{array}$ \\
\hline 25 & 9 & 11 & 1 & 21 & 625 & 646 & 3.25 \\
\hline 37 & 18 & 49 & 1 & 68 & 707 & 775 & 8.51 \\
\hline 38 & 5 & 25 & 1 & 31 & 1626 & 1657 & 1.87 \\
\hline 39 & 4 & 22 & 5 & 31 & 1856 & 1887 & 1.64 \\
\hline \multirow[t]{2}{*}{40} & 6 & 30 & 2 & 38 & 1323 & 1361 & 2.79 \\
\hline & 42 & 137 & 10 & 189 & 6137 & 6326 & $2.9 \%$ \\
\hline
\end{tabular}

Chect: (Cnsprayed.) Trees-For Comparison

\begin{tabular}{llllllll}
$\begin{array}{l}\text { Tree } \\
\text { No. }\end{array}$ & $\begin{array}{l}\text { Calyx } \\
\text { wormy }\end{array}$ & $\begin{array}{c}\text { Side } \\
\text { wormy }\end{array}$ & $\begin{array}{c}\text { Stem } \\
\text { wormy }\end{array}$ & $\begin{array}{l}\text { Total } \\
\text { wormy }\end{array}$ & $\begin{array}{c}\text { Sound } \\
\text { fruit }\end{array}$ & $\begin{array}{c}\text { Total } \\
\text { fruit }\end{array}$ & $\begin{array}{c}\text { Per cent } \\
\text { wormy }\end{array}$ \\
50 & 304 & 244 & 48 & 596 & 1352 & 1948 & 30.59 \\
51 & 348 & 343 & 45 & 736 & 1107 & 1843 & 39.93 \\
52 & 246 & 150 & 28 & 424 & 485 & 909 & 46.63 \\
53 & 150 & 89 & 18 & 257 & 290 & 547 & 46.98 \\
& 1048 & $\overline{826}$ & $\overline{139}$ & $\overline{2013}$ & $\overline{3234}$ & $\overline{5247}$ & $38.3 \%$ \\
\hline
\end{tabular}

Tree No. 49. Intended for check, but by mistake mist sprayed May 13

$\begin{array}{cccccccc}\text { Tree } & \text { Calyx } & \text { Side } & \text { Stem } & \text { Total } & \text { Sound } & \text { Total } & \text { Per cent } \\ \text { No. } & \text { Wormy } & \text { wormy } & \text { Wormy } & \text { wormy } & \text { fruit } & \text { fruit } & \text { wormy } \\ 49 & 19 & 77 & 10 & 106 & 738 & 844 & 12.5 \%\end{array}$


fruit to have been 8.9 per cent. Expressing these percentages in terms of worm-free fruit we have. Western method, 97.4; Eastern method, 96.7, and the check trees, 65.9.

By comparing the stem wormy apples of the two methods. of spraying an interesting point was observed. It will be seen that less worms entered the stem end of the fruit where the four mist sprays were applied than in the case of one coarse-highpressure spraying. In the growth of the apple it becomes too heavy for the stem to hold it in an upright position as at first and so the fruit topples over, as it were, thus presenting another cup-the stem cup, if you please-into which the material from the late sprays collect and a dose of poison is thus placed in position ready for the larvae of the second brood that may try to enter at this end. While the tables of the unsprayed trees show that but a small per cent of worms enter the fruit at this place the results in the different methods of spraying evidently points to the fact that by filling the stem cup for the second, or later broods where they occur, some good will be accomplished.

In using a coarse nozzle it was found that about twice as much material was applied as in the case of the mist spray; therefore, the amunt of arsenate of lead in the material for the two methods would be in the relation of two to three, although but one pound of the poison to fifty gallons of water was used in the Western method and three pounds in the Eastern. More time was consumed in spraying according to the former method than that of the latter because special care was taken to fill all the calyx cups, but it must also be remembered that only one application was made with the coarse-high-pressure spray while four sprayings were done with the mist spray during the season. Therefore it appears that if the Western method will always give the good results obtained in this test much time would be saved to our Eastern orchardists by using the one-coarse-highpressure spray already adopted in the far west. With but one or two tests we are not in a position to say which of the two methods herein described will prove of the most value in point 


\section{TABLE III}

Record of Codling Moth Work-Drops and Picked Fruit Combined

Western Method of Spraying-Coarse Spray, High Pressure, One Application

\begin{tabular}{cccccccc}
$\begin{array}{c}\text { Tree } \\
\text { No. }\end{array}$ & $\begin{array}{l}\text { Calyx } \\
\text { wormy }\end{array}$ & $\begin{array}{c}\text { Side } \\
\text { wormy }\end{array}$ & $\begin{array}{c}\text { Stem } \\
\text { wormy }\end{array}$ & $\begin{array}{c}\text { Total } \\
\text { wormy }\end{array}$ & $\begin{array}{c}\text { Sound } \\
\text { fruit }\end{array}$ & $\begin{array}{c}\text { Total } \\
\text { fruit }\end{array}$ & $\begin{array}{c}\text { Per cent } \\
\text { wormy }\end{array}$ \\
2 & 11 & 116 & 20 & 147 & 3184 & 3331 & 4.41 \\
3 & 0 & 49 & 12 & 61 & 2615 & 2676 & 2.27 \\
5 & 2 & 61 & 6 & 69 & 3566 & 3635 & 1.89 \\
16 & 4 & 39 & 7 & 50 & 2493 & 2543 & 1.97 \\
17 & 4 & 64 & 10 & 78 & 2796 & 2874 & 2.71 \\
& -21 & 329 & 55 & 405 & 14654 & 15059 & $2.6 \%$ \\
\hline
\end{tabular}

Eastern Method of Spraying-Mist Spray, Medium Pressure, Four Applications

\begin{tabular}{lccccccc}
$\begin{array}{l}\text { Tree } \\
\text { No. }\end{array}$ & $\begin{array}{c}\text { Calyx } \\
\text { wormy }\end{array}$ & $\begin{array}{c}\text { Side } \\
\text { wormy }\end{array}$ & $\begin{array}{c}\text { Stem } \\
\text { wormy }\end{array}$ & $\begin{array}{c}\text { Total } \\
\text { wormy }\end{array}$ & $\begin{array}{c}\text { Sound } \\
\text { fruit }\end{array}$ & $\begin{array}{c}\text { Total } \\
\text { fruit }\end{array}$ & $\begin{array}{c}\text { Per cent } \\
\text { wormy }\end{array}$ \\
25 & 32 & 28 & 2 & 62 & 1071 & 1133 & 5.46 \\
37 & 28 & 60 & 5 & 93 & 1003 & 1096 & 8.52 \\
38 & 13 & 35 & 2 & 50 & 2261 & 2311 & 2.16 \\
39 & 10 & 27 & 6 & 43 & 2290 & 2333 & 1.84 \\
40 & 8 & 36 & 2 & 46 & 1826 & 1872 & 2.45 \\
\hline
\end{tabular}

Check (Unsprayed) Trees-For Comparison

\begin{tabular}{|c|c|c|c|c|c|c|c|}
\hline $\begin{array}{l}\text { Tree } \\
\text { No. }\end{array}$ & $\begin{array}{l}\text { Calyx } \\
\text { wormy }\end{array}$ & $\begin{array}{l}\text { Side } \\
\text { wormy }\end{array}$ & $\begin{array}{l}\text { Stem } \\
\text { wormy }\end{array}$ & $\begin{array}{l}\text { Total } \\
\text { wormy }\end{array}$ & $\begin{array}{l}\text { Sound } \\
\text { fruit }\end{array}$ & $\begin{array}{l}\text { Total } \\
\text { fruit }\end{array}$ & $\begin{array}{l}\text { Per cent } \\
\text { wormy }\end{array}$ \\
\hline 50 & 634 & 315 & 59 & 1008 & 2535 & 3543 & 28.45 \\
\hline 51 & 727 & 406 & 65 & 1198 & 2361 & 3559 & 33.66 \\
\hline 52 & 557 & 191 & 41 & 789 & 992 & 1781 & 44.30 \\
\hline \multirow[t]{2}{*}{53} & 315 & 145 & 27 & 487 & 832 & 1319 & 36.92 \\
\hline & 2233 & 1057 & 192 & 3482 & 6720 & 10202 & $34.1 \%$ \\
\hline
\end{tabular}

Tree No. 49. Intended for check, but by mistake mist sprayed May 13

\begin{tabular}{cccccccc}
\hline Tree & Calyx & Side & Stem & Total & Sound & Total & Per cent \\
No. & wormy & wormy & wormy & wormy & fruit & fruit & $\begin{array}{c}\text { wormy } \\
\text { worm }\end{array}$ \\
49 & 33 & 84 & 10 & 127 & 1304 & 1431 & $8.9 \%$
\end{tabular}


of time and money to the grower. However, in this experiment, the tables before us show that either way has been of much value when compared with the unsprayed trees. In fact, as to final results in this ease there is practically no difference between the Eastern and Western methods.

\section{Spraying for the Plum Curculio.}

The plum curculio ranking next to the codling moth as an apple pest in West Virginia a record was kept of the injury caused by this insect along with that of the codling moth just described. This was done that we might get a better idea of the amount of benefit to be derived by spraying with arsenical poisons to control this pest, and, also to note the relative merits of the Eastern and Western methods in checking it.

Table IV (p. 138) gives the total number of apples from the trees selected for counts of the different methods of spray. ing and the check trees and are the same as those used in the codling moth test. This table shows 87.4 per cent curculio-free fruit where the Western method was used and 86.1 per cent curculio-free apples with the Eastern method, while the unsprayed trees gave but 67.8 per cent sound fruit. In other words where the one-coarse-high-pressure spray was used 12.5 per cent of the fruit was stung and where the four mist sprays were applied 13.9 per cent of the apples were injured, and the unsprayed trees gave 32.1 per cent of punctured fruit.

In these obervations on the work of the plum eurculio it will be seen that the results obtained by the two kinds of spraying do not vary materially from what was secured in the case of the codling moth test, however not as many stung-free fruits were obtained as worm-free ones. This bears out the fact that the plum curculio is a more difficult insect to. control than is the codling moth. 
TABLE IV

\section{Record of Plum Curculic Work-Drop and Picked Fruit}

Western Method of Spraying-Coarse Spray, High Pressure, One Application

\begin{tabular}{|c|c|c|c|c|}
\hline Tree & No. Fruit & No. Fruit & Total & Per cent \\
\hline No. & Punctured & Sound & Fruit & Punctured \\
\hline 2 & 513 & 2818 & 3331 & 15.70 \\
\hline 3 & 360 & 2316 & 2676 & 13.41 \\
\hline 5 & 368 & 3267 & 3635 & 10.12 \\
\hline 16 & 294 & 2249 & 2543 & 11.56 \\
\hline \multirow[t]{2}{*}{17} & 351 & 2523 & 2874 & 12.21 \\
\hline & 1886 & & 15059 & $12.5 \%$ \\
\hline
\end{tabular}

Eastern Method of Spraying-Mist Spray, Medium Pressure, Four Applications

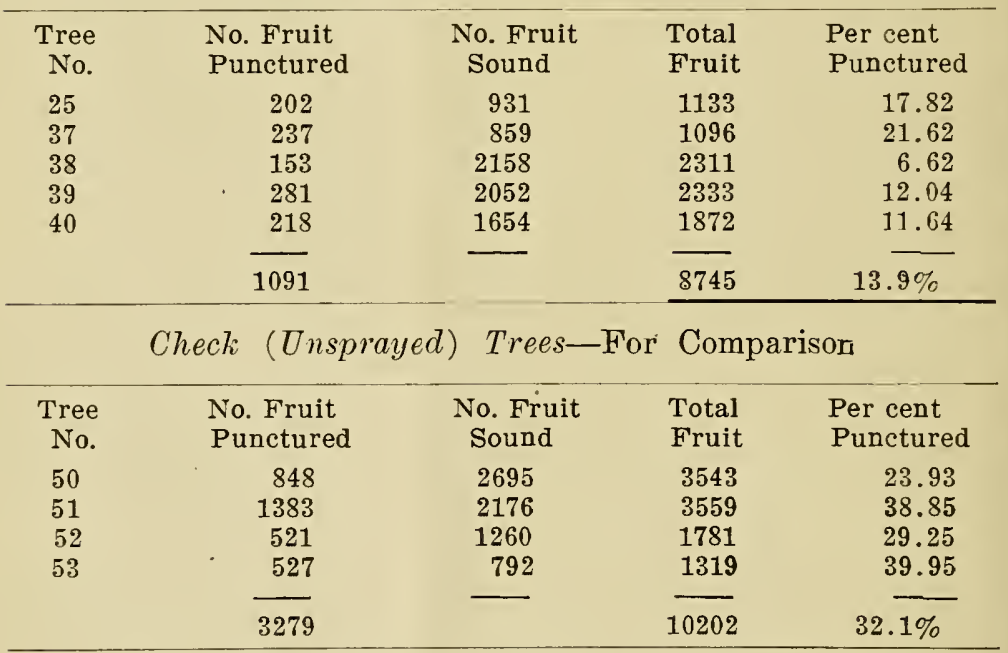

Tree No. 49. Intended for check, but by mistake mist sprayed May 13

\begin{tabular}{ccccc}
\hline Tree & No. Fruit & No. Fruit & Total & Per cent \\
No. & Punctured & Sound & Fruit & Punctured \\
49 & 121 & 1310 & 1431 & $8.4 \%$
\end{tabular}


Returns from Proper Spraying.

In order to better impress upon the minds of our readers the good results that ean be secured by thorough spraying, photographs were made of the picked fruit, three of which are reproduced in this bulletin, (plate II opp. p. 140) showing apples from onc tree each of the Eastern and Western method of spraying and also that from a check tree. The fruit is arranged in three piles-sound, curculio stung, and wormy-and well illustrates to the eye what may be expected from thorough spraying for the codling moth and plum curculio. Some of the fruit in the wormy piles are also stung by the curulio, but no codling wormy apples occur in the curculio stung piles. Going a little further with our illustration and figuring up the sound apples from the sprayed and unsprayed trees we get a very stiking contrast. Since there is an average of about 360 Ben Davis apples in a barrel, the fruit from the check tree shown in the picture gave about two barrels of sound apples; while four and a half barrels of such fruit was secured from the tree sprayed according to the Eastern method and four and three fourths barrels where the Western method was followed. There were over one and a half barrels of wormy fruit from the unsprayed tree, while only about a peck of such fruit was obtained from either of the sprayed tree.

\section{Conclusion.}

The results given above between sprayed and unsprayed trees can be obtained by any fruit grower by simply spraying thoroughly with the proper material and at the right time. In order to fully realize the amount of worm-free fruit to be secured by spraying just leave a tree or two without any application and spray the balance thoroughly at the right time. In harvesting the crop carefully observe the wormy apples from the sprayed and unsprayed trees. It will surprise you!

As a "clincher" to the previous statement it might be said 
that in an orchard of thirteen acres, thirteen years old owned by The J. N. Thatcher Company of Berkeley county, West Virginia, thorough spraying at the right time and with the proper material so reduced the damage from insects and diseases that the owners realized Six Thousand Dollars ( $\$ 6000.00)$ from the corp of 1909 above the expenses of picking and packing. Scarcely any wormy apples could be found in this orchard at picking time. The frontispiece of this Bulletin shows a view in the orchard a few days before the crop mentioned was harvested. 



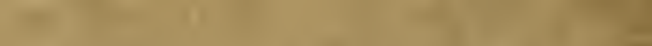
a .

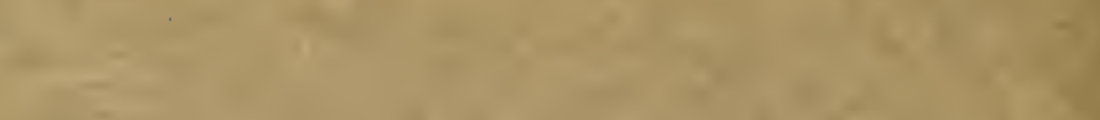

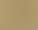

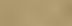

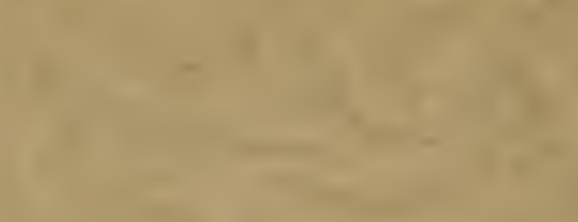

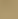
$+2$<smiles>CC1CC1</smiles>

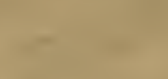

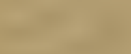

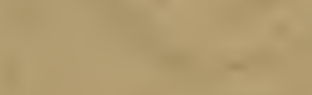<smiles>C1CCCCC1</smiles>

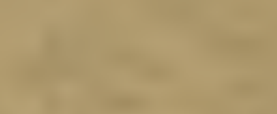<smiles>CC</smiles>

10

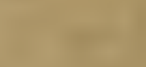

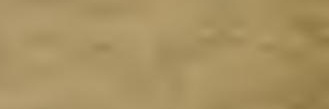

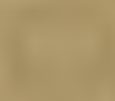
$-5$

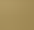




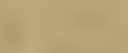

$\sqrt{2}+x^{2}$

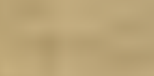

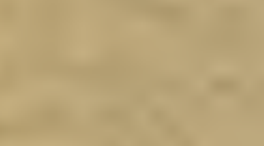

1

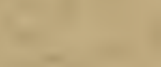

$=0$

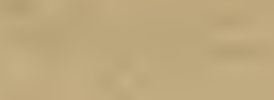

$\sqrt{2}+x^{2}$

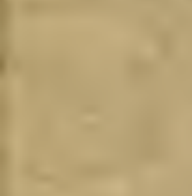

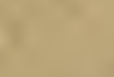

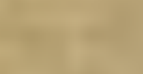

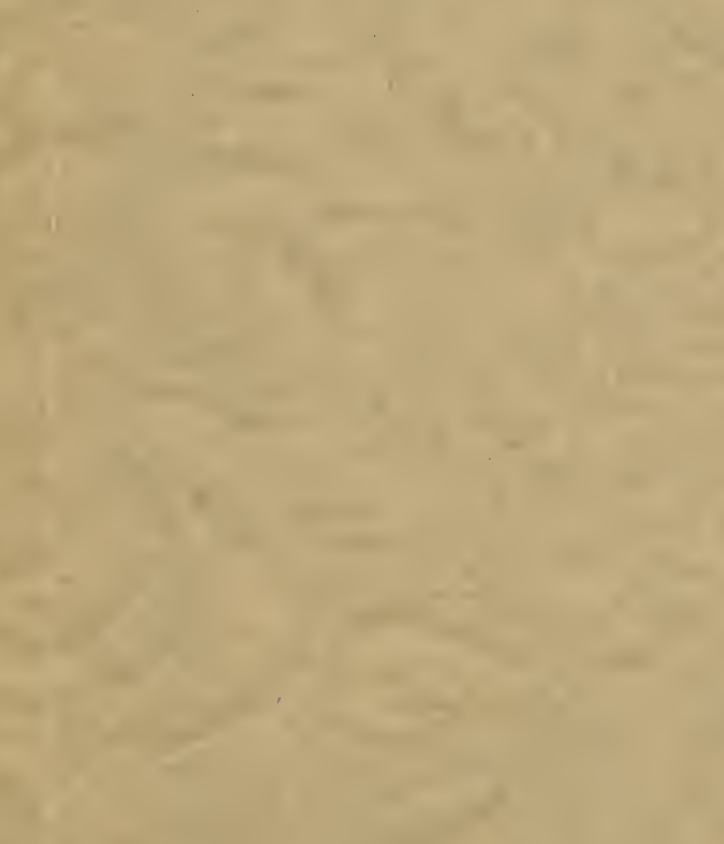

$\sqrt{2}$

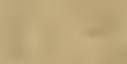


(2) 